\title{
Human Bone Xenografts: from Preclinical Testing for Regenerative Medicine to Modeling of Diseases
}

\author{
Mark Seow Khoon Chong ${ }^{1}$ C Chaolemeng $\mathrm{Bao}^{2} \cdot \operatorname{King}$ Pan $\mathrm{Ng}^{3} \cdot \mathrm{Jing} \mathrm{Lim}^{1}$. \\ Jerry Kok Yen Chan ${ }^{2,3,4}$
}

Published online: 13 August 2016

(C) Springer International Publishing AG 2016

\begin{abstract}
Xenografting involves the transplantation of human tissue or cells into animal models and is an important tool for regenerative medicine research. Implantation of engineered human bone tissues into animal models, for example, is performed in preclinical evaluations of product safety and efficacy. With the advent of improved experimental methodologies, these models are further being exploited to interrogate molecular mechanisms and physiological interactions in vivo. In parallel to these developments, patient-derived xenograft murine models of cancer are increasingly being studied for various applications in cancer research and therapy; it follows that xenograft models in tissue engineering may be adapted for such approaches. In this review, we first discuss the development of human bone xenograft models to recapitulate physiological states in regenerative medicine. Subsequently, we discuss the use of these techniques for applications in modeling pathological states in skeletal oncology, namely, hematopoietic malignancies, bone metastatic disease, and primary bone malignancy.
\end{abstract}

This article is part of the Topical Collection on Preclinical Animal Models in Regenerative Medicine

Mark Seow Khoon Chong

MarkChong@ntu.edu.sg

1 Division of Bioengineering, School of Chemical and Biomedical Engineering, Nanyang Technological University, Singapore 637459, Singapore

2 Department of Obstetrics and Gynaecology, Yong Loo Lin School of Medicine, National University of Singapore, Singapore 119228, Singapore

3 Cancer and Stem Cell Biology Program, Duke-NUS Graduate Medical School, Singapore 169857, Singapore

4 Department of Reproductive Medicine, KK Women's and Children's Hospital, Singapore 229899, Singapore
Keywords Tissue engineering · Disease models · Hematopoietic niche $\cdot$ Skeletal oncology $\cdot$ Bone metastasis

\section{Introduction}

Xenografting into animal models is commonly performed in the preclinical evaluation of engineered tissues for regenerative medicine, with the major objective of demonstrating safety and efficacy of the engineered constructs for regenerative and reconstructive applications. These range from small animal models, where the engineered tissue constructs are typically implanted in an ectopic location, to large animals, where they are usually implanted orthotopically [1], with many experimental tools specifically designed for the evaluation of physiological responses to the implanted constructs in vivo. For example, novel and powerful imaging modalities have been developed to observe vascular development, in order to shed light on angiogenic process following implantation of engineered bone tissues [2,3]. Advances in multimodal imaging have also made it possible to concurrently monitor such responses in parallel [4] and/or multiple cell types homing and migrating to the implanted constructs [5].

Beyond applications in regenerative medicine, human bone xenografted models have also proven useful as experimental models of skeletal disease, by providing a platform to study human-specific pathologies. Leveraging on the customized experimental techniques described above, these models provide unique opportunities to study disease states in vivo, which would otherwise be impossible on human subjects. Such use of humanderived tissue is of particular value in characterizing speciesspecific behavior and provides specific insights into disease etiology and drug efficacy over existing animal disease models. This review thus focuses on the use of xenografted bone tissues as experimental models in musculoskeletal oncology, beginning 
with a brief overview of xenografted bone models for regenerative medicine, and leading to current studies in the use of engineered bone tissue for the study of bone marrow-residing leukemias, bone-metastatic cancers, and bone-primary tumors.

\section{Engineered Human Bones in Xenograft Models: Preclinical Testing for Regenerative Applications}

\section{Animal Models for Bone Regenerative Studies}

A wide range of mammals have been used for preclinical evaluations of tissue-engineered bones. Small rodents such as mice and rats are generally preferred in early-stage studies where large numbers are required [6]. Additionally, genetically engineered mice (GEM) are available that provide a plethora of experimental settings for study design, including diseased phenotypes and, more specifically, immunocompromised mice for xenografting studies $[7,8]$. However, rodent models are limited in the space and volume of implants afforded, and implantation is commonly performed ectopically in the subcutaneous pockets or peritoneal cavity.

In the evaluation of regenerative capacity, orthotopic implantations are preferred and most commonly performed on larger animals such as rabbits, sheep, and dogs $[9,10]$. In these models, a critically sized, non-healing defect is surgically introduced into the animal skeleton and subsequently treated with the engineered tissue graft. Such models are isomorphic to the clinical situation and purportedly demonstrate better approximation to human bone biology and composition, as compared to their small animal counterparts [11].

Defect type and location are also varied to reflect different clinical scenarios or to facilitate specific experimentation. For example, segmental defects in load-bearing long bones, such as the femoral and tibial diaphysis, more accurately reflect the mechanical loads experienced in vivo. [12-14]. Such defect sites have well-defined geometry and location, facilitating studies for the tracking of new bone formation and vascular infiltration and mechanical testing for the evaluation of torsional torque and bending strength as measures of functional recovery [15]. In contrast, non-load-bearing facial/cranial defects may be employed that usually do not require additional fixation. These models are less challenging technically and more amenable to small animal experimentation. Additionally, the absence of (usually metallic) fixtures avoid confounding effects of biomechanical stress shielding [16] and render the surgical site more amenable to radiographic imaging, facilitating serial, non-invasive monitoring.

\section{Evaluation Reparative Outcomes}

The accurate evaluation of physiological responses represents another major challenge in the design and conduct of experiments with xenografted animal models. Mineralization and/or bone bridging in the bone graft, as determined by the mineral extracellular matrix (ECM) formed, is most often taken as a primary indicator of bone healing and is most readily observed through radiographic imaging. This is commonly performed with portable imaging systems (such as C-arms) to provide gross observations, while computed tomography (CT) techniques have gained popularity for high-resolution three-dimensional reconstructions, which allow the acquisition of quantifiable parameters in the region, including volume and area of mineral tissue [17]. Histological staining of sample sections is also commonly performed at end-point. Hematoxylin and eosin (H\&E) stain is mostly used, which allows to observe not only ECM formation, but also the ingrowth of cells. Von Kossa staining and Masson's trichrome staining are also commonly used to identify mineral phosphates and ECM organization [18]. Immunohistochemistry techniques may be further performed to allow the specific detection of genes or cell types, providing evidence for mechanistic explanations and findings.

In addition to morphological observations, biomechanical tests are often performed to quantify the restoration of structural function to the fracture site. Depending on implant site, these include torsional, bending, and push-out tests, which are performed on the extracted tissue samples [19]. In order to meet specific requirements for biocompatibility testing, additional protocols for the evaluation of neo-vascularization, chimerism, inflammation, tumorigenesis, and other aspects of safety and efficacy are also readily available [9, 20-23].

\section{Behavior of Engineered Bone Grafts In Vivo}

Arguably, the most crucial aspect of bone tissue engineering lies in predicting the performance of engineered grafts in vivo. Ectopic models, most commonly conducted in mouse models, provide a measure of capacity bone formation after implantation. This process is highly dependent on factors intrinsic (osteoinductive and osteoconductive properties) and extrinsic (vascularization, immune reaction) to the graft itself [24]. Provided with adequate conditions, subcutaneously implanted engineered bone grafts have been shown to be capable of engraftment and formation of woven bone [25]. A major advantage of using murine models is the availability of genetically modified mice, in particular immunocompromised strains that demonstrate greater "take" of implanted tissues. Thus implanted, engineered bone constructs carrying mesenchymal and endothelial progenitors are capable of generating osteogenic and vasculogenic tissue of human origin [26•]. Due to technical challenges arising from size limitations, however, these models are not commonly employed in orthotopic settings, which would provide greater predictive value of the efficacy of bone grafts for the treatment of fractures. Thus, ectopic models are typically used instead as a screen in basic 
biocompatibility studies; further evaluations in more homologous settings, such as in non-healing, critically sized fracture models, are generally required.

In a review of published articles from January 2000 to November 2015, 175 articles were found in which tissue engineering approaches were used for the treatment of critical-sized bone defects. Among animal species used, rodents were employed in more than $70 \%$ of studies in the field (Fig. 1 b), of which rats were favored for their size and ease of handling, particularly in critical-sized defect models. Anatomical location of the defect site is highly dependent on the choice of animals used (Fig. 1 c); small species such as mice and rats mainly focused on large bones such as cranium and femurs, while the larger animals are amenable for surgery on smaller bones such as radii and metatarsii, in accordance with the study objectives.

The experimental settings of reviewed studies were summarized according to the nature of donor cells (animal origin or human origin) and animal models used (Fig. 1). Across the models, bone marrow-derived mesenchymal stem cells (BMSC) and adipose tissue-derived stem cells (ASC) were used most often, accounting for nearly $70 \%$ of all studies. BMSC were most popularly employed in autologous/
Fig. 1 The experimental settings of reviewed studies were summarized according to the nature of donor cells (animal origin or human origin) and animal models used. a The MSC employed in such studies are derived from more accessible tissue, such as adipose, muscle, dental pulp, periosteum, umbilical cord, cord blood, amniotic fluid, and even urine. b Among animal species used, rodents were employed in more than $70 \%$ of studies in the field. c Anatomical location of the defect site is highly dependent on the choice of animals used

\section{a}

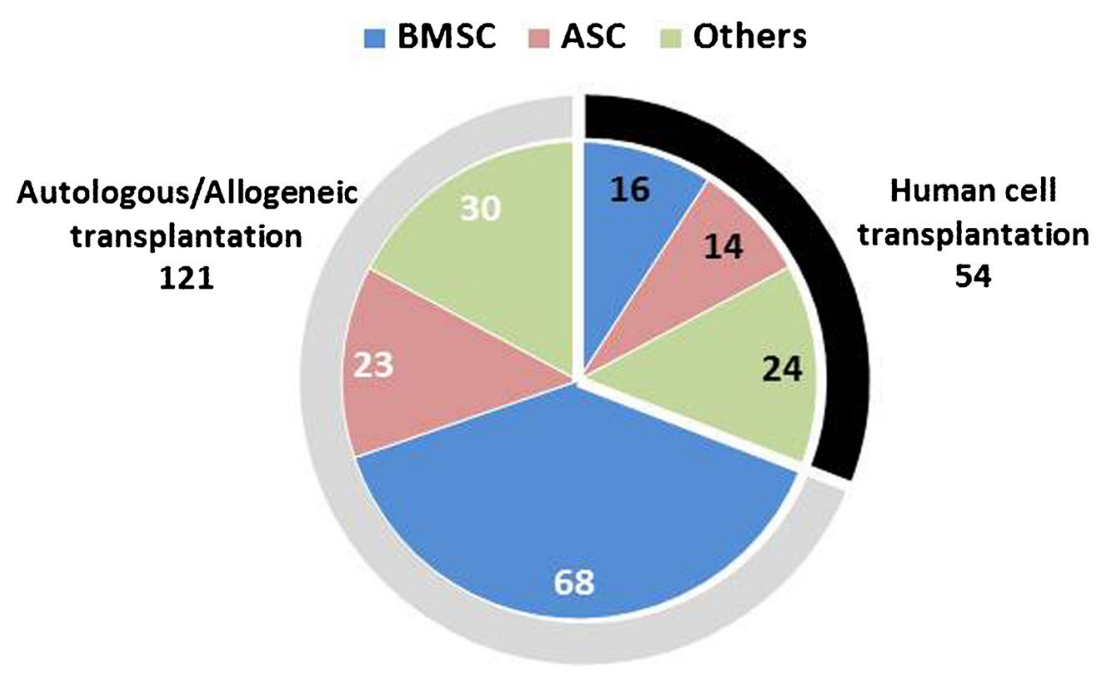

b

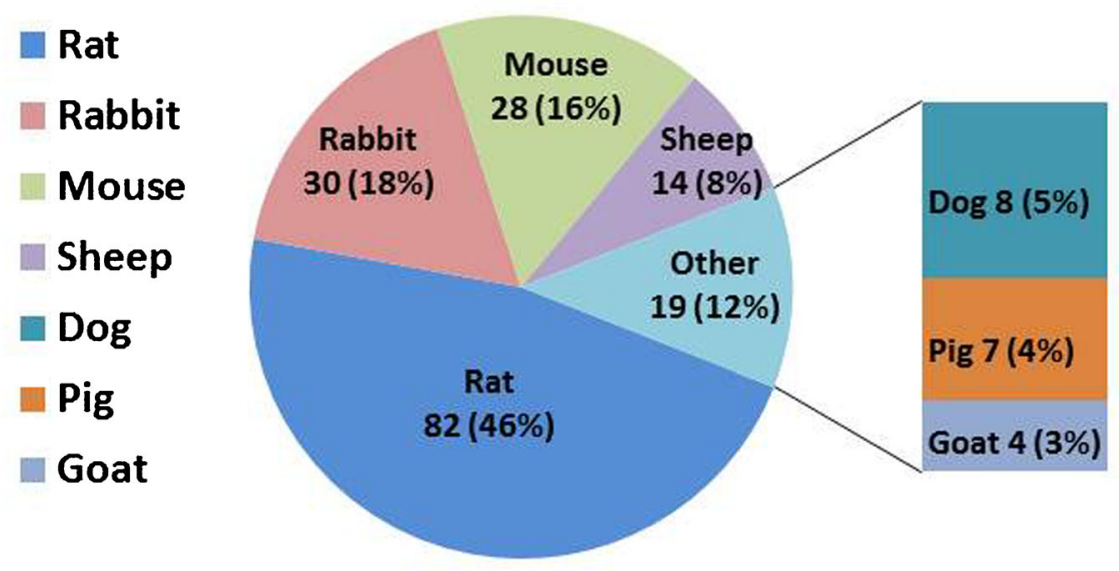

C

\begin{tabular}{ccccccccc}
\hline Species & Cranium & Mandible & Femur & Tibia & Radius & Ulna & Metatarsus Iliac wing \\
\hline Rat & 39 & 2 & 38 & 3 & - & - & - & - \\
\hline Rabbit & 7 & 2 & 3 & 3 & 14 & 1 & - \\
\hline Mouse & 24 & - & 3 & 1 & - & - & - & - \\
\hline Sheep & 1 & - & 2 & 6 & 1 & - & 4 & - \\
\hline Dog & 3 & 5 & - & - & 1 & 1 & - & - \\
\hline Pig & 2 & 1 & 2 & 2 & - & - & - & - \\
\hline Goat & - & - & 1 & 2 & - & - & - & 1
\end{tabular}


allogeneic cell transplantation studies (68 out of 121), but less so in xenogeneic settings. However, this does not imply BMSC to be less suited for xenotransplants, but are simply more easily isolated and better established than their counterparts in allogeneic settings and thus preferred in such experiments [27-29]. In contrast, xenotransplant experiments in regenerative medicine are chiefly performed to evaluate the therapeutic performance of various cell sources for clinical applications (Fig. 1). It follows that the MSC employed in such studies are derived from more accessible tissue, such as adipose, muscle, dental pulp, periosteum, umbilical cord, cord blood, amniotic fluid, and even urine (Fig. 1a). Additionally, xenografting studies using primitive stem cells such as induced pluripotent stem cells (iPSC) and embryonic stem cells (ESC) have also been performed. It should be noted that while these cells provide greater ease of use in the clinical setting [30], they may, in themselves, demonstrate poorer approximation of osteogenic processes in vivo [31].

Findings from the reviewed studies generally suggest significant osteogenesis and healing after implantation of the engineered bone constructs, as compared to the control groups such as an empty scaffold [32], or even against positive controls such as autograft and BMP-2 treatment [33, 34]. About $7 \%$ (13 out of 175) of the studies showed little healing after the treatment with cellular scaffolds, with compromised efficacy ascribed to inappropriate choice of cells or scaffolds, poor conditions, or insufficient amount of cells. Notably, in eight studies using osteoblast cell sources, four showed no improvement to the healing, with two showing positive results only when BMP-2-transduced cell lines were used [35-42].

A major conundrum in preclinical models lies in the conflicting need to evaluate the performance of human-derived cell sources in isomorphic models, against confounding effects of host responses to the xenogeneic cell source. Notably, in studies that compared implantation of human BMSC against autologous cell lines, human cell lines resulted in inferior healing efficacy, even where no inflammation responses was detected [14, 43]. Moreover, many other studies using human cell sources claimed disappearance of implanted human cells after weeks of transplantation, even with strict immunosuppression regimes in place [44-46]. As such, such tests may not be valid as defining models of clinical safety and efficacy, but rather, the experimental results should be interpreted at "risk markers" [47].

\section{Engineered Human Bones in Xenograft Models: Disease Models in Oncology}

Bone, as an organ, performs many important biological functions aside from providing structural support, including metabolic homeostasis, hematopoiesis, and stem cell maintenance [48]. Much of these functions are regulated by various niche cells (mesenchymal, endothelial, osteoblast/osteoclast, and immune cells) in the complex, interconnected bone marrow microenvironment [49•]. In recent years, it has become evident that the bone marrow microenvironment nurtures not only normal stem cells (mainly hematopoietic) but also leukemic stem cells [50, 51] and bone metastatic cancers [52], with many of these studies conducted on animals xenografted with human cancer cells.

Transplantation of human cancer (stem) cells or tumor tissue into immunodeficient mice has been performed over the past 50 years. Initially developed as a means of tumor propagation, xenoimplanted tumors are currently being employed in etiological and drug-response studies. Such models offer significant advantages over mice genetically engineered with oncogenes (oncomice) to spontaneously develop cancer, including their ability to capture human cancer-specific behavior [53]. However, in contrast to oncomice, however, the tumors are often ectopically implanted into subcutaneous or renal capsule spaces, which are unable to provide appropriate microenvironmental effects. Even if orthotopically engrafted, given the fundamental differences between human and mice [54•], the murine model might not recapitulate the physiological process of cancer development and stem cell maintenance in human. Bereft of a suitable microenviroment, such models suffer from poor "take" of injected human cancer cells and/or incapability to recapitulate disease features.

Research efforts to generate more "humanized" mouse models have yielded enhanced human cell engraftment, each with their attendant limitations. These include (1) supplementation of selected human cytokines, either by exogenous administration or genetic expression (limited by the absence of stromal cells and difficulties in maintaining cytokine concentrations at physiological level [54•]) and (2) co-transplantation of human mesenchymal niche cells into the mouse bone marrow (limited by an inability to maintain the xenoplanted mesenchymal cells in vivo for a long term $[55,56])$. More recently, tissue engineering approaches have been developed to create human bone organoids in mice, in an effort to provide the humanized environment to accommodate human cancer cells. Here, we summarize the recent advances involving the use of engineered human bone in murine models, especially in the context of skeletal oncology.

\section{Hematopoietic Malignancies}

Experimental models of leukemia are the most commonly studied xenograft models, due largely to the ready availability of patient cancer cell samples. A major limitation in the use of these models, however, lies in the low xenograft efficiency [57]. Even with positive "take," many engrafted cancer cells display a lack of propensity for expansion, especially for those samples taken from less aggressive diseases such as Myelodysplastic Syndrome (MDS) or chronic myeloid 
leukemia (CML) [58]. To meet the need for better xenograft models, engineered organoid human bone may be implanted in murine models, providing a human bone-derived niche for stem cell engraftment and proliferation (Table 1). Works by Holzapfel et al., Reinisch et al., and Scotti et al. [61••, 63•, 64•] have yielded highly encouraging results, with evidence of long-term hematopoietic stem cells taking residence within the engineered human bone (Fig. 2).

While this represents a proof of principle in generating better xenograft models, further improvements and standardization of the models are needed. Future endeavors are likely to include coupling of engineering human bone with mice that are more human cell-compatible. One example is the use of NSG-SGM3 (or NSGS), a transgenic NSG strain that constitutively produces human cytokines SCF, GM-CSF, and IL3 into their serum [54•]. The NSG-SGM3 is superior in accepting and supporting the proliferation of human cells. Additionally, the appropriate cellular milieu for the establishment of a suitable hematopoietic niche needs to be identified. In particular, despite years of research and usage, human MSC sources are largely heterogenous and remain poorly defined. Good-quality and standardized MSC are requisite for engineering the human bone marrow niche reliably. Given the recent advantage in manipulation of embryonic stem (ES) [65] and iPS cells, these might provide a more reliable and reproducible source of MSC, for niche engineering. Finally, in reconstructing such a complex biological system as the bone marrow, bio-inspired engineering approaches based on developmental biology will be critical [66]. The process of cartilage remodeling in bone through endochondral ossification has been shown to be integral in the formation of a hematopoietic niche [67] and may be adapted to engineer a functional bone marrow, as demonstrated by Reinisch et al. [61••] and Scotti et al. [64•].

\section{Bone Metastatic Disease}

Metastasis is estimated to cause $90 \%$ of cancer deaths [68], with the bone being a particularly common site of metastasis for cancers of the lung, breast, and prostate. Bone metastastatic disease (BMD) is associated with high mortality and can also often be observed in cancers of the colon, stomach, bladder, uterus, rectum, thyroid, and kidney [69]. This is most pronounced in prostate cancer, which shows a peculiar predilection for bone, with 8 out of 10 advanced prostate cancer patients developing BMD [70]. BMD is also responsible for significant morbidity, resulting in bone pain, hypercalcemia, and pathological fractures [71].

Following escape from the primary tumor, cells are disseminated via hematogenous routes to distant tissues. It follows that premetastatic tissues provide cues to elicit cancer cell extravasation and migration into a metastatic-permissive environment. In bone metastasis, the process is believed to

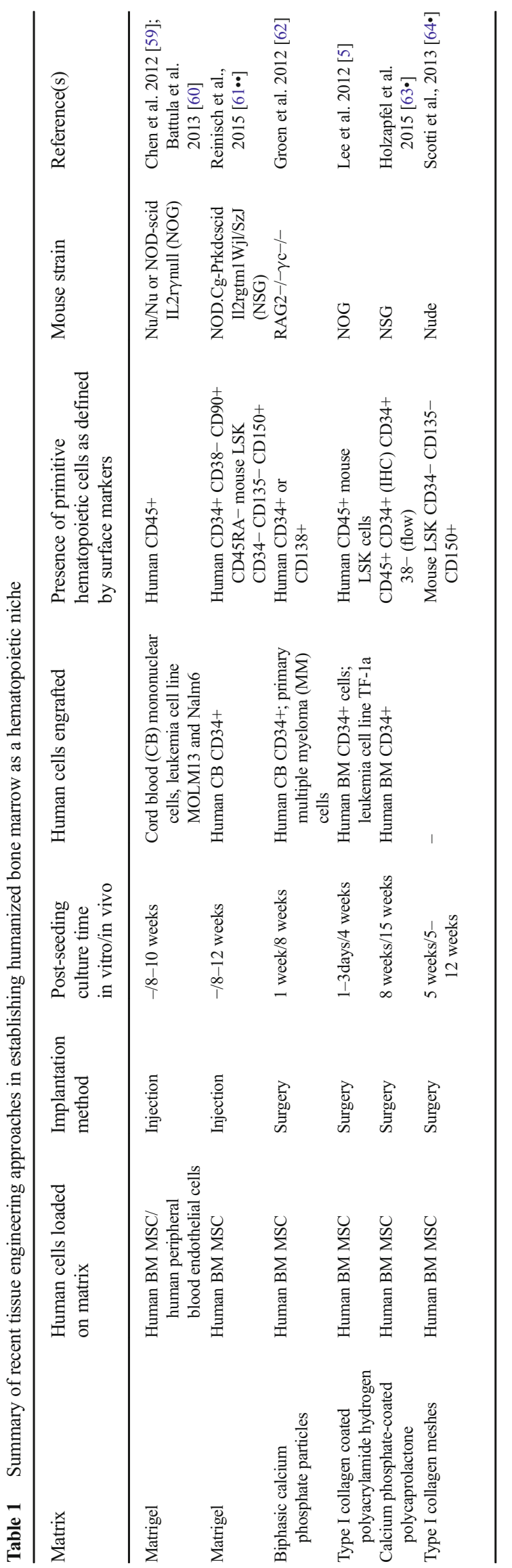


a

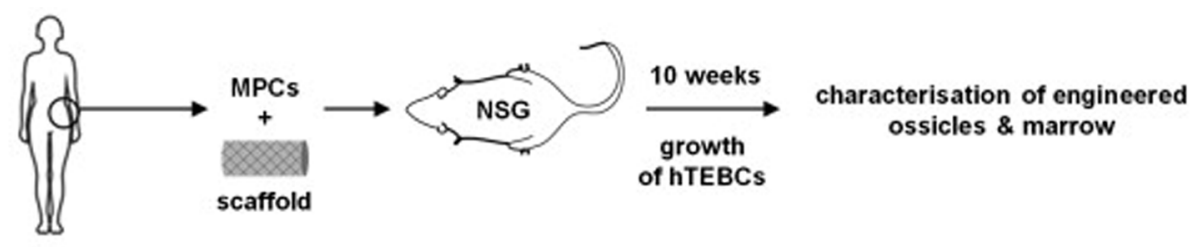

b
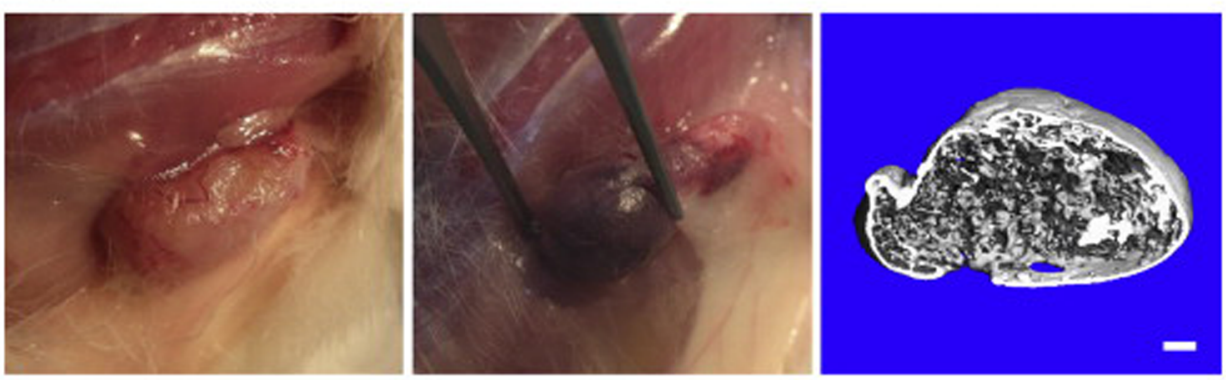

c
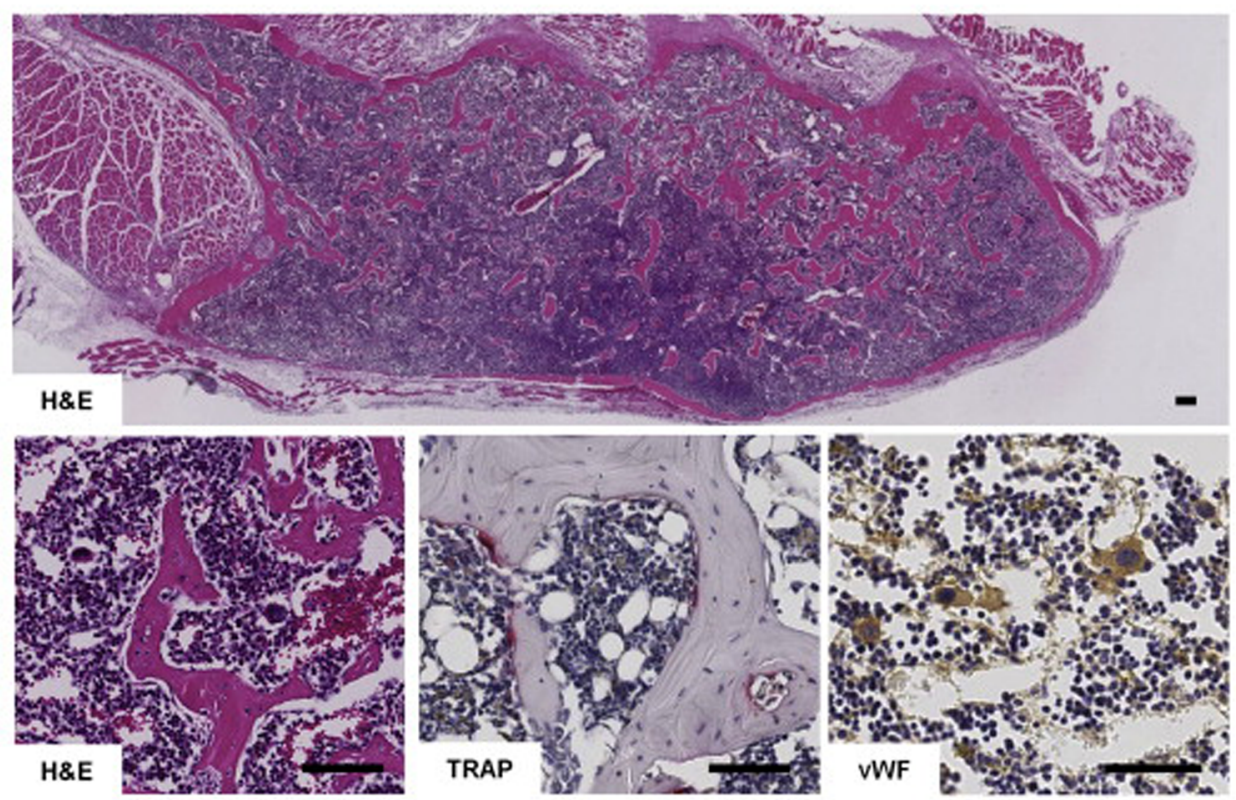

d
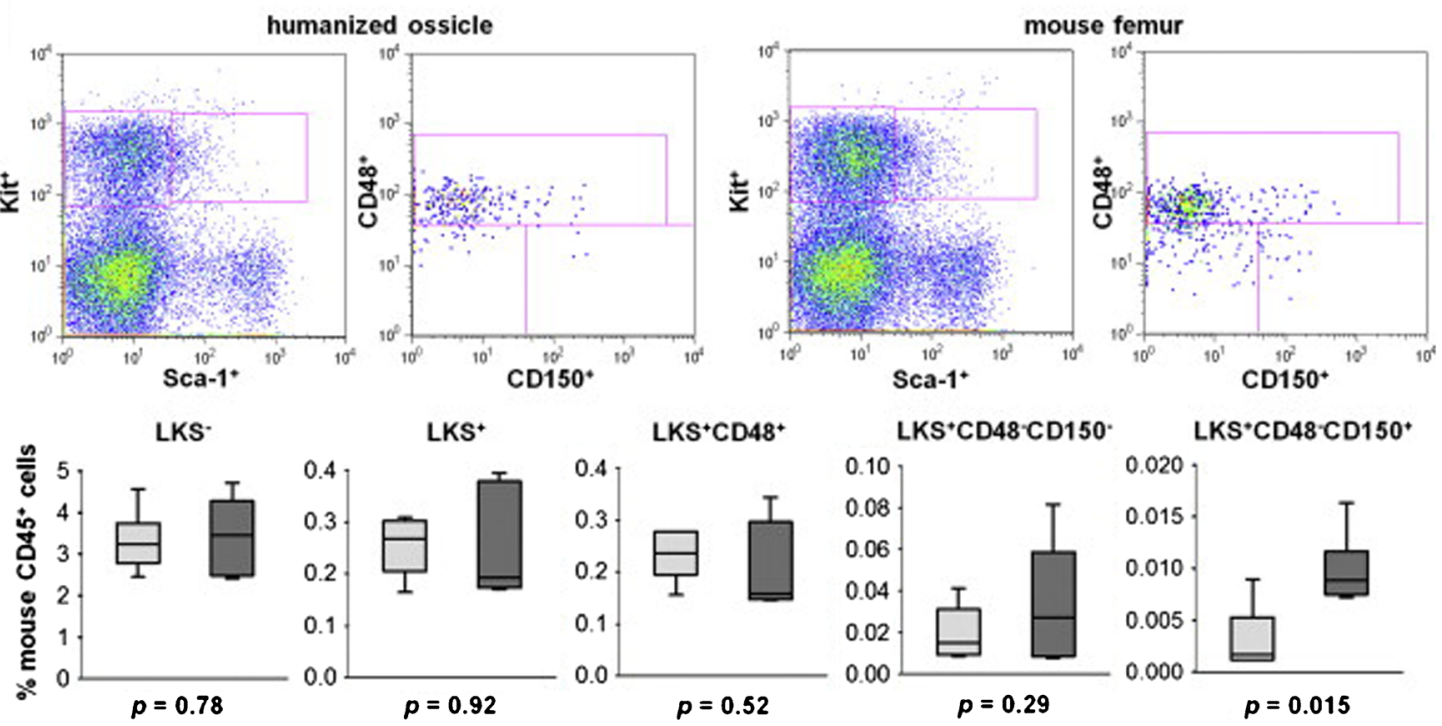

Fig. 2 Works by Holzapfel et al., Reinisch et al., and Scotti et al. [61••, 63•, 64•] have yielded highly encouraging results, with evidence of long-term hematopoietic stem cells taking residence within the engineered human bone 
mirror the cytokine-mediated "homing" of hematopoietic stem cells to bone marrow [72] and bone-trophic prostate cancer cells have been shown to hijack hematopoietic stem cell niches within the trebaculae [73]. Following dissemination to these sites, significant cross-talks between the disseminated tumor cell (DTC) and the microenvironment continue to take place, leading to transformation into a "malignant niche" and activation of DTC towards a metastatically active phenotype. Much of these interactions are governed by osteoblasts, mesenchymal progenitors, and endothelial cells within the sinusoidal hematopoietic niche [49•, 74].

The role of bone marrow-derived MSC in BMD progression, in particular, has been the topic of much debate. Contrasting results have been demonstrated, for example for tumor-promoting $[75,76]$ and tumor-suppressive effects of MSC [77] in the microenvironment. Part of these differences may be explained by the phenotypic state of the MSC. Endochondral differentiation of MSC towards osteoblastic lineages is known to elicit chemoattractants, such as SDF-1 and MCP-1, and thus attract and retain B leukemia and metastatic breast cancer cells [78-80]. Once homed to bone marrow, tumor cells have been shown to interact with MSC or with their progeny (such as osteoblasts and adipocytes) to induce both pro-tumorigenic and inhibitory effects [81-83]. In light of such findings, it is clear that early crosstalk between disseminated tumor cells and the bone microenvironment is key to metastatic activation and disease progression [84], highlighting an urgent unmet need for adequate models of the disease.

Many experimental models of bone metastasis have been developed over the past century, which have been integral in identifying key molecular interactions in the bone metastatic niche. These models, however, are lacking in various aspects (Table 2). More recently, models combining features from the above have been employed that may provide more accurate representation of the clinical situation. Nemeth et al. first showed preferential homing of circulating prostate cancer cells towards subcutaneously implanted human fetal bone fragments over host skeleton in immunodeficient mice [95]. Subsequently, Moreau et al. found that co-implantation of engineered bone and tumor grafts also enables recapitulation of breast cancer metastatic events [96]. Besides increased accessibility to samples, tissue-engineered bone exhibits a major advantage in the ability to manipulate the engineered human bone prior to implantation [97]. For example, varying the stage of differentiation was found to influence extent of metastasis, suggesting a role of osteoblastic progenitors in homing [96]. Similarly, altering the state of the ECM may yield differences in metastatic responses. Tumor migration and proliferation, skeletal remodeling, and even molecular events [98] may then be interrogated longitudinally, aided by their extra-skeletal location and close proximity to skin [99]. The scaffolds used may also be modified to study the contributions of specific molecules in the process: modification of silk scaffolds with receptor activator of nuclear factor kappa-B ligand (RANKL), for example, increased breast cancer metastasis to subcutaneously implanted engineered bone constructs [100]. Additionally, the use of human cells facilitate the tracking of human-specific proteins, isolating graft-specific responses $[101 \bullet \bullet]$. Other advantages of this system include amenability to genetic manipulation prior to implantation and the use of human tissue to reduce confounders arising from xenogenic host cells. The use of tissue-engineered bone in a metastasis model thus allows the generation of a range of premetastatic conditions, followed by longitudinal and real-time assessment of critical cancer parameters. These include tumor size, extent of skeletal remodeling, and expression of osteogenic markers. Using such approaches, Holzapfel et al. demonstrated species-specific homing of metastatic prostate cancer cells to engineered human bone, where they contribute to significant osteolysis and cancer growth, recapitulating the clinical features of the disease $[101 \bullet \cdot]$. These studies and others suggest the utility of murine models with xenografted bone implants as humanized models of bone metastatic disease, providing unique opportunities to investigate poorly understood aspects of the disease [102•].

A major research theme in tissue engineering involves vascularization of implanted constructs, in order to promote tissue viability and engraftment. Establishment of a functional vascular network in xenografted bone is critical for effective

Table 2 Summary of existing models in the study of bone metastasis

\begin{tabular}{llll}
\hline & Experimental set up & Ref & Limitations \\
\hline Two-dimensional (Petri dish cultures) & Cancer cells + ECM & {$[85]$} & Lack three-dimensional organization \\
& Mixed cellular co-cultures & {$[86]$} & \\
Three-dimensional (engineered tissue) & Cancer cells + ECM in a scaffold & {$[87-89]$} & Unable to recapitulate early metastatic \\
& Cellular co-cultures & {$[90]$} & events such as extravasation. Difficult to image \\
& Spheroidal cultures & & \\
& Subcutaneous implant of metastatic graft model & {$[91]$} & Unable to recapitulate human-specific responses \\
In vivo models & Tibial injection of cancer cells & {$[92]$} & Technical challenges in imaging and studying \\
& Genetically engineered mouse models & {$[93]$} & early events \\
& Intracardiac injection of cancer cells & {$[94]$} & \\
\hline
\end{tabular}


models of bone metastasis, considering the roles of vascular transport and bone marrow endothelial cells in cancer cell transport and homing [103]. Several strategies have been developed to promote vascularization of engineered tissue following implantation, including biomaterial and scaffold modification, use of growth factors, and the use of co-culture systems [104]. The use of angiogenic cells in co-culture has also been explored, and endothelial lineages [26•, 105-108] have been incorporated into engineered tissue constructs to promote vessel formation. These angiogenic cells spontaneously form prevascular networks in vitro and anastomose rapidly following implantation, leading to perfusion of the construct. In experiments involving MSC-EPC grafts, the neovasculature formed within the graft is found to comprise cells of human origin, connected to host vasculature, suggesting concurrent vasculogenesis and angiogenesis [108]. It is anticipated that such efforts will have significant impact on refining the current xenograft models by reproducing the heterocellular composition of the bone marrow, which, in turn, are expected to have profound effects on cancer cell behavior $[109,110]$.

\section{Primary Bone Malignancy}

Bone-primary malignancies, including osteosarcoma (OS), are generally rare in occurrence, affecting less than $1 \%$ of the general population in the USA [111]. OS may be categorized according to its location within the bone structures (intramedullary, cortex-associated) or disease entity (Paget's disease, fibrous dysplasia, Mazabraud's disease) [112]. A peculiar hallmark of the disease is the bimodal age distribution: OS affects mainly adolescents (10-14 years old) and older adults ( $>65$ years old) $[111,113]$ and represents a significant health concern for these populations. However, the disease remains poorly understood, with severe limitations in existing diagnostic and treatment options [112]. A review of www. clinicaltrials.org (accurate to January 2016) revealed 349 clinical trials, of which 149 are completed (42.7\%); 145 are still recruiting, inviting, or active $(41.5 \%) ; 44$ were terminated, withdrawn, or suspended (12.6\%); 10 are not yet recruiting (2.9\%); and only 1 approved for marketing $(0.3 \%)$. These statistics suggest extremely poor clinical translation of investigated techniques, highlighting the need for adequate disease models to investigate the molecular pathogenesis of OS.

Since 2011, there have been 5863 publications about OS, forming approximately $32.9 \%$ of all publications to date (information from Web of Science, accurate to January 2016), demonstrating the increase in research prominence of OS over the last 5 years. Approximately $11.0 \%$ of these publications were related to the use of animal models for studying OS, mostly involving murine models (6.4\% or 373 publications) or canine models contributed (4.6\%; 265 publications). It is interesting to note that dogs are predisposed to OS, leading to their utility as spontaneous OS models [114]. Canine models of OS have been identified to present parallel genetic features to human OS [115], including similarly dysregulated $p 53, c$-sis, and $c-m y c$ profiles [116]. Crucially, they capture critical clinical features of the disease, such as diffuse pulmonary metastasis [117]. Using such models, Ranieri et al. correctly predicted the efficacy of a regime based on intra-arterial cisplatin and irradiation to achieve local tumor control and retain limb function $[118,119]$. Canine studies are, however, largely prohibitive in terms of costs and scale, severely limiting their routine application in research studies. Moreover, significant differences remain between canine and human osteosarcomas [120].

In the murine models, human xenografts are introduced via inoculation of cells subcutaneously [121], direct injection into the tibia [122], or subperiosteal injection [123]. Thus generated, these models act as avatars to elucidate optimal drug regimes or as disease models for the evaluation of the role of oncogenic molecules in disease progression, including $p 53$ [121], IL-6/ STAT3 [122], and ROCK1 [124]. Of these, orthotopic models are favored for better approximation to the osseous tumor microenvironment; multimodal positron emission tomography, computed tomography, magnetic resonance imaging, and bioluminescent imaging may be performed to achieve highresolution imaging of tumor interactions with bone [125]. Technical challenges of such approaches remain, however, such as mortality arising from the intrabone injections [123], technically demanding imaging techniques and difficulty in harvesting or retrieving the xenografted cells.

As above, the use of tissue engineering approaches to generate bone (in this case, osteosarcomas) may provide similar value as an experimental model for osteosarcoma research. In fact, osteosarcoma lines such as MG62 and Saos-2 have historically been used in studies evaluating the compatibility of novel biomaterials with osteogenic cells [126, 127], providing early evidence of the technical feasibility of engineering an osteosarcoma in vitro. According to Villasante et al., an in vitro model of Ewing's sarcoma was found to be capable of replicating several features of the native bone tumor niche, including recovery of a hypoxic and glycolytic phenotypefeatures that are lost in monolayer cultures [128]. To such constructs, it has been suggested that co-cultures with human-derived mesenchymal stromal cells and/or endothelial cells may be introduced to mimic the cellular heterogeneity of the in vivo environment, further improving the biological fidelity of such models [129]. Corollary to this, such assembled human osteosarcoma-bone constructs may be implanted into immunocompromised mice, possessing sufficient biological complexity to capture the pathophysiological processes in tumor progression. This approach has, to our knowledge, not yet been attempted, and it remains to be seen if this model will provide a more clinically relevant model, particularly if malignant transformation and metastatic distribution can be faithfully reproduced. 


\section{Conclusions}

Xenograft models are commonly used to establish the safety and efficacy of engineered tissue grafts prior to translation to clinics. More recently, such models have gained attention as experimental models of disease. Xenografted engineered bone tissues, in particular, have applications in models of leukemia, bone metastatic disease, and osteosarcoma. Major advantages of this approach include recapitulation of human-specific physiology including cancer cell homing and drug responses. Additionally, these models benefit from the extensive range of tools developed for evaluating both graft and host responses in preclinical tests. Significant challenges remain, however, which need to be addressed before such models may be reliably used. Graft viability is compromised by implantation, due to a range of issues including immunogenic responses to the xenograft and the lack of adequate vascularization. This is particularly pronounced in orthotopic, large animal models, which suffer from both immunorejection issues and compromised nutrient supply compounded by the size of constructs. As such, disease models remain largely limited to rodent models, in which research is currently being undertaken to improve the tolerability of the hosts and the biological performance of the grafts.

Acknowledgments $\mathrm{MC}$ and NKP are supported by the National Research Foundation Singapore under its Cooperative Basic Research Grant-New Investigator Grant (CBRG-NIG) NMRC/BNIG/2007/ 2013 and NMRC/BNIG/2015/2014, respectively, administered by the Singapore Ministry of Health's National Medical Research Council (NMRC). JKYC received salary support from the Ministry of Health's National Medical Research Council (NMRC/CSA/043/2012), Singapore.

\section{Compliance with Ethical Standards}

Conflict of Interest Chong Seow Khoon Mark, Bao Chaolemeng, Ng King Pan, Lim Jing, and Chan Kok Yen Jerry declare that they have no conflict of interest.

Human and Animal Rights and Informed Consent This article does not contain any studies with human or animal subjects performed by any of the authors.

\section{References}

Papers of particular interest, published recently, have been highlighted as:

- Of importance

•- Of major importance

1. Muschler GF, Raut VP, Patterson TE, Wenke JC, Hollinger JO. The design and use of animal models for translational research in bone tissue engineering and regenerative medicine. Tissue Eng B Rev. 2010;16(1):123-45. doi:10.1089/ten.TEB.2009.0658.
2. Saran U, Gemini Piperni S, Chatterjee S. Role of angiogenesis in bone repair. Arch Biochem Biophys. 2014;561:109-17. doi:10.1016/j.abb.2014.07.006.

3. Upputuri PK, Sivasubramanian K, Mark CSK, Pramanik M. Recent developments in vascular imaging techniques in tissue engineering and regenerative medicine. BioMed Res Int. 2015;2015:783983. doi:10.1155/2015/783983.

4. Helmrich U, Di Maggio N, Guven S, Groppa E, Melly L, Largo $\mathrm{RD}$, et al. Osteogenic graft vascularization and bone resorption by VEGF-expressing human mesenchymal progenitors. Biomaterials. 2013;34(21):5025-35. doi:10.1016/j. biomaterials.2013.03.040.

5. Lee J, Li M, Milwid J, Dunham J, Vinegoni C, Gorbatov R, et al. Implantable microenvironments to attract hematopoietic stem/cancer cells. Proc Natl Acad Sci U S A. 2012;109(48):19638-43. doi:10.1073/pnas.1208384109.

6. Mills LA, Simpson AH. In vivo models of bone repair. J Bone Joint Surg (Br). 2012;94(7):865-74. doi:10.1302/0301-620X.94 B7.27370.

7. Levi B, James AW, Nelson ER, Vistnes D, Wu B, Lee M, et al. Human adipose derived stromal cells heal critical size mouse calvarial defects. PLoS One. 2010;5(6):e11177. doi:10.1371 /journal.pone.0011177.

8. Rentsch C, Rentsch B, Breier A, Spekl K, Jung R, Manthey S, et al. Long-bone critical-size defects treated with tissue-engineered polycaprolactone-co-lactide scaffolds: a pilot study on rats. J Biomed Mater Res A. 2010;95(3):964-72. doi:10.1002/jbm. a.32878.

9. Wu J, Wang Q, Fu X, Wu X, Gu C, Bi J, et al. Influence of immunogenicity of allogeneic bone marrow mesenchymal stem cells on bone tissue engineering. Cell Transplant. 2015. doi:10.3727/096368915x687967.

10. Ronca A, Guarino V, Raucci MG, Salamanna F, Martini L, Zeppetelli S, et al. Large defect-tailored composite scaffolds for in vivo bone regeneration. J Biomater Appl. 2014;29(5):715-27. doi:10.1177/0885328214539823.

11. Pearce AI, Richards RG, Milz S, Schneider E, Pearce SG. Animal models for implant biomaterial research in bone: a review. Eur Cell Mater. 2007;13:1-10.

12. Foo T, Reagan J, Watson JT, Moed BR, Zhang Z. External fixation of femoral defects in athymic rats: Applications for human stem cell implantation and bone regeneration. J Tissue Eng. 2013;4: 2041731413486368. doi:10.1177/2041731413486368.

13. Zhao Z, Yang D, Ma X, Zhao H, Nie C, Si Z. Successful repair of a critical-sized bone defect in the rat femur with a newly developed external fixator. Tohoku J Exp Med. 2009;219(2):115-20.

14. Niemeyer P, Szalay K, Luginbuhl R, Sudkamp NP, Kasten P. Transplantation of human mesenchymal stem cells in a non-autogenous setting for bone regeneration in a rabbit critical-size defect model. Acta Biomater. 2010;6(3):900-8. doi:10.1016/j. actbio.2009.09.007.

15. Endres S, Hiebl B, Hagele J, Beltzer C, Fuhrmann R, Jager V, et al. Angiogenesis and healing with non-shrinking, fast degradeable PLGA/CaP scaffolds in critical-sized defects in the rabbit femur with or without osteogenically induced mesenchymal stem cells. Clin Hemorheol Microcirc. 2011;48(1):29-40. doi:10.3233/ch2011-1406.

16. Liu N, Lyu X, Fan H, Shi J, Hu J, Luo E. Animal models for craniofacial reconstruction by stem/stromal cells. Curr Stem Cell Res Ther. 2014;9(3):174-86.

17. Kallai I, Mizrahi O, Tawackoli W, Gazit Z, Pelled G, Gazit D. Microcomputed tomography-based structural analysis of various bone tissue regeneration models. Nat Protocols. 2011;6(1):10510. http://www.nature.com/nprot/journal/v6/n 1 /abs/nprot.2010.180.html\#supplementary-information. 
18. Rentsch C, Schneiders W, Manthey S, Rentsch B, Rammelt S. Comprehensive histological evaluation of bone implants. Biomatter. 2014;4. doi:10.4161/biom.27993.

19. Nau C, Henrich D, Seebach C, Schroeder K, Fitzsimons SJ, Hankel S, et al. Treatment of large bone defects with a vascularized periosteal flap in combination with biodegradable scaffold seeded with bone marrow derived mononuclear cellsan experimental study in rats. Tissue Eng Part A. 2015. doi:10.1089/ten.TEA.2015.0030.

20. Eldesoqi K, Henrich D, El-Kady AM, Arbid MS, Abd El-Hady BM, Marzi I, et al. Safety evaluation of a bioglass-polylactic acid composite scaffold seeded with progenitor cells in a rat skull critical-size bone defect. PLoS One. 2014;9(2):e87642. doi:10.1371 /journal.pone.0087642.

21. Choi HJ, Kim JM, Kwon E, Che JH, Lee JI, Cho SR, et al. Establishment of efficacy and safety assessment of human adipose tissue-derived mesenchymal stem cells (hATMSCs) in a nude rat femoral segmental defect model. J Korean Med Sci. 2011;26(4): 482-91. doi:10.3346/jkms.2011.26.4.482.

22. Liu G, Zhang Y, Liu B, Sun J, Li W, Cui L. Bone regeneration in a canine cranial model using allogeneic adipose derived stem cells and coral scaffold. Biomaterials. 2013;34(11):2655-64. doi:10.1016/j.biomaterials.2013.01.004.

23. Zou D, Zhang Z, He J, Zhang K, Ye D, Han W, et al. Blood vessel formation in the tissue-engineered bone with the constitutively active form of HIF-1alpha mediated BMSCs. Biomaterials. 2012;33(7):2097-108. doi:10.1016/j.biomaterials.2011.11.053.

24. Fröhlich M, Grayson WL, Wan LQ, Marolt D, Drobnic M, Vunjak-Novakovic G. Tissue engineered bone grafts: biological requirements, tissue culture and clinical relevance. Curr Stem Cell Res Ther. 2008;3(4):254-64.

25. Wang XJ, Huang H, Yang F, Xia LG, Zhang WJ, Jiang XQ, et al. Ectopic study of tissueengineered bone complex with enamel matrix proteins, bone marrow stromal cells in porous calcium phosphate cement scaffolds, in nude mice. Cell Prolif. 2011;44(3):274 82. doi:10.1111/j.1365-2184.2011.00750.x.

26. Liu Y, Teoh SH, Chong MS, Lee ES, Mattar CN, Randhawa NK, et al. Vasculogenic and osteogenesis-enhancing potential of human umbilical cord blood endothelial colony-forming cells. Stem Cells. 2012;30(9):1911-24. doi:10.1002/stem.1164. Study showing the use of human progenitor cells to generate functional human bone and vascular network in a xenotransplant

27. Berner A, Reichert JC, Woodruff MA, Saifzadeh S, Morris AJ, Epari DR, et al. Autologous vs. allogenic mesenchymal progenitor cells for the reconstruction of critical sized segmental tibial bone defects in aged sheep. Acta Biomater. 2013;9(8):7874-84. doi:10.1016/j.actbio.2013.04.035.

28. Kern S, Eichler H, Stoeve J, Klüter H, Bieback K. Comparative analysis of mesenchymal stem cells from bone marrow, umbilical cord blood, or adipose tissue. Stem Cells. 2006;24(5):1294-301. doi:10.1634/stemcells.2005-0342.

29. Chen W, Liu J, Manuchehrabadi N, Weir MD, Zhu Z, Xu HH. Umbilical cord and bone marrow mesenchymal stem cell seeding on macroporous calcium phosphate for bone regeneration in rat cranial defects. Biomaterials. 2013;34(38):9917-25. doi:10.1016 j.biomaterials.2013.09.002.

30. Malgieri A, Kantzari E, Patrizi MP, Gambardella S. Bone marrow and umbilical cord blood human mesenchymal stem cells: state of the art. Int J Clin Exp Med. 2010;3(4):248-69.

31. Zhang ZY, Teoh SH, Chong MS, Schantz JT, Fisk NM, Choolani $\mathrm{MA}$, et al. Superior osteogenic capacity for bone tissue engineering of fetal compared with perinatal and adult mesenchymal stem cells. Stem cells (Dayton, Ohio). 2009;27(1):126-37. doi:10.1634 /stemcells.2008-0456.
32. Yuan J, Cui L, Zhang WJ, Liu W, Cao Y. Repair of canine mandibular bone defects with bone marrow stromal cells and porous beta-tricalcium phosphate. Biomaterials. 2007;28(6):1005-13. doi:10.1016/j.biomaterials.2006.10.015.

33. Peterson B, Zhang J, Iglesias R, Kabo M, Hedrick M, Benhaim P, et al. Healing of critically sized femoral defects, using genetically modified mesenchymal stem cells from human adipose tissue. Tissue Eng. 2005;11(1-2):120-9. doi:10.1089/ten.2005.11.120.

34. Viateau V, Guillemin G, Bousson V, Oudina K, Hannouche D, Sedel L, et al. Long-bone critical-size defects treated with tissueengineered grafts: a study on sheep. J Orthop Res. 2007;25(6): 741-9. doi:10.1002/jor.20352.

35. Bagher Z, Rajaei F, Shokrgozar M. Comparative study of bone repair using porous hydroxyapatite/ betatricalcium phosphate and xenograft scaffold in rabbits with tibia defect. Iran Biomed J. 2012;16(1):18-24.

36. Gallego L, Junquera L, Garcia E, Garcia V, Alvarez-Viejo M, Costilla $\mathrm{S}$, et al. Repair of rat mandibular bone defects by alveolar osteoblasts in a novel plasma-derived albumin scaffold. Tissue Eng Part A. 2010;16(4):1179-87. doi:10.1089/ten. TEA.2009.0517.

37. Haberstroh K, Ritter K, Kuschnierz J, Bormann KH, Kaps C, Carvalho C, et al. Bone repair by cell-seeded 3D-bioplotted composite scaffolds made of collagen treated tricalciumphosphate or tricalciumphosphate-chitosan-collagen hydrogel or PLGA in ovine critical-sized calvarial defects. J Biomed Mater Res B Appl Biomater. 2010;93(2):520-30. doi:10.1002/jbm.b.31611.

38. Keskin M, Kelly CP, Moreira-Gonzalez A, Lobocki C, Yarim M, Kaplan S, et al. Repairing criticalsized rat calvarial defects with a periosteal cell-seeded small intestinal submucosal layer. Plast Reconstr Surg. 2008;122(2):400-9. doi:10.1097/PRS.0b013 e31817d6206.

39. Sommar P, Junker JP, Strandenes E, Ness C, Hansson T, Johnson $\mathrm{H}$, et al. Osteogenically-induced human dermal fibroblasts as a tool to regenerate bone. J Plast Surg Hand Surg. 2013;47(1):813. doi:10.3109/2000656x.2012.731411.

40. Tayton E, Purcell M, Smith JO, Lanham S, Howdle SM, Shakesheff KM, et al. The scale-up of a tissue engineered porous hydroxyapatite polymer composite scaffold for use in bone repair: an ovine femoral condyle defect study. J Biomed Mater Res A. 2015;103(4):1346-56. doi:10.1002/jbm.a.35279.

41. Wehrhan F, Amann K, Molenberg A, Lutz R, Neukam FW, Schlegel KA. PEG matrix enables cellmediated local BMP-2 gene delivery and increased bone formation in a porcine critical size defect model of craniofacial bone regeneration. Clin Oral Implants Res. 2012;23(7):805-13. doi:10.1111/j.1600-0501.2011.02223.x.

42. Wehrhan F, Amann K, Molenberg A, Lutz R, Neukam FW, Schlegel KA. Critical size defect regeneration using PEG-mediated BMP-2 gene delivery and the use of cell occlusive barrier membranes - the osteopromotive principle revisited. Clin Oral Implants Res. 2013;24(8):910-20. doi:10.1111/j.16000501.2012.02489.x.

43. Niemeyer P, Schonberger TS, Hahn J, Kasten P, Fellenberg J, Suedkamp N, et al. Xenogenic transplantation of human mesenchymal stem cells in a critical size defect of the sheep tibia for bone regeneration. Tissue Eng A. 2010;16(1):33-43. doi:10.1089 /ten.TEA.2009.0190.

44. Chuang CK, Lin KJ, Lin CY, Chang YH, Yen TC, Hwang SM, et al. Xenotransplantation of human mesenchymal stem cells into immunocompetent rats for calvarial bone repair. Tissue Eng Part A. 2010;16(2):479-88. doi:10.1089/ten.TEA.2009.0401.

45. Jager M, Degistirici O, Knipper A, Fischer J, Sager M, Krauspe R. Bone healing and migration of cord blood-derived stem cells into a critical size femoral defect after xenotransplantation. J Bone Miner Res. 2007;22(8):1224-33. doi:10.1359/jbmr.070414. 
46. Zhang ZY, Teoh SH, Chong MS, Lee ES, Tan LG, Mattar CN, et al. Neovascularization and bone formation mediated by fetal mesenchymal stem cell tissue-engineered bone grafts in critical-size femoral defects. Biomaterials. 2010;31(4):608-20. doi:10.1016/j. biomaterials.2009.09.078.

47. Williams DF. The same but different: regulation of tissue engineering and regenerative medicine in the context of regional and international standards and expectations. Tissue Eng A. 2015;21(2324):2781-2. doi:10.1089/ten.tea.2015.0470.

48. Yin $\mathrm{T}, \mathrm{Li} \mathrm{L}$. The stem cell niches in bone. J Clin Invest. 2006;116(5):1195-201. doi:10.1172/JCI28568.

49. Morrison SJ, Scadden DT. The bone marrow niche for haematopoietic stem cells. Nature. 2014;505(7483):327-34. doi:10.1038/nature12984. An excellent review to illustrate the complexity of bone marrow microenvironment

50. Lane SW, Scadden DT, Gilliland DG. The leukemic stem cell niche: current concepts and therapeutic opportunities. Blood. 2009;114(6):1150-7. doi:10.1182/blood-2009-01-202606.

51. Konopleva MY, Jordan CT. Leukemia stem cells and microenvironment: biology and therapeutic targeting. J Clin Oncol Off J Am Soc Clin Oncol. 2011;29(5):591-9. doi:10.1200 /JCO.2010.31.0904.

52. Pedersen EA, Shiozawa Y, Pienta KJ, Taichman RS. The prostate cancer bone marrow niche: more than just 'fertile soil'. Asian J Androl. 2012;14(3):423-7. doi:10.1038/aja.2011.164.

53. Richmond A, Su Y. Mouse xenograft models vs GEM models for human cancer therapeutics. Dis Model Mech. 2008;1(2-3):78-82. doi:10.1242/dmm.000976.

54. Rongvaux A, Takizawa H, Strowig T, Willinger T, Eynon EE, Flavell RA, et al. Human hematolymphoid system mice: current use and future potential for medicine. Annu Rev Immunol. 2013;31:635-74. doi:10.1146/annurev-immunol-032712095921. An excellent review on human-to-mouse xenotransplantation models used for hematological researches

55. Medyouf H, Mossner M, Jann JC, Nolte F, Raffel S, Herrmann C, et al. Myelodysplastic cells in patients reprogram mesenchymal stromal cells to establish a transplantable stem cell niche disease unit. Cell Stem Cell. 2014;14(6):824-37. doi:10.1016/j. stem.2014.02.014.

56. Muguruma Y, Matsushita H, Yahata T, Yumino S, Tanaka Y, Miyachi H, et al. Establishment of a xenograft model of human myelodysplastic syndromes. Haematologica. 2011;96(4):543-51. doi:10.3324/haematol.2010.027557.

57. Pearce DJ, Taussig D, Zibara K, Smith LL, Ridler CM, Preudhomme C, et al. AML engraftment in the NOD/SCID assay reflects the outcome of AML: implications for our understanding of the heterogeneity of AML. Blood. 2006;107(3):1166-73. doi:10.1182/blood-2005-06-2325.

58. Zhang B, Strauss AC, Chu S, Li M, Ho Y, Shiang KD, et al. Effective targeting of quiescent chronic myelogenous leukemia stem cells by histone deacetylase inhibitors in combination with imatinib mesylate. Cancer Cell. 2010;17(5):427-42. doi:10.1016 /j.ccr.2010.03.011.

59. Chen Y, Jacamo R, Shi YX, Wang RY, Battula VL, Konoplev S, et al. Human extramedullary bone marrow in mice: a novel in vivo model of genetically controlled hematopoietic microenvironment. Blood. 2012;119(21):4971-80. doi:10.1182/blood-2011-11389957.

60. Battula VL, Chen Y, Cabreira Mda G, Ruvolo V, Wang Z, Ma W, et al. Connective tissue growth factor regulates adipocyte differentiation of mesenchymal stromal cells and facilitates leukemia bone marrow engraftment. Blood. 2013;122(3):357-66. doi:10.1182/blood-2012-06-437988.

61.• Reinisch A, Etchart N, Thomas D, Hofmann NA, Fruehwirth M, Sinha S, et al. Epigenetic and in vivo comparison of diverse MSC sources reveals an endochondral signature for human hematopoietic niche formation. Blood. 2015;125(2):249-60. doi:10.1182/blood-2014-04-572255. A scalable approach to produce humanized bone construct

62. Groen RW, Noort WA, Raymakers RA, Prins HJ, Aalders L, Hofhuis FM, et al. Reconstructing the human hematopoietic niche in immunodeficient mice: opportunities for studying primary multiple myeloma. Blood. 2012;120(3):e9-16. doi:10.1182/blood2012-03-414920.

63. Holzapfel BM, Hutmacher DW, Nowlan B, Barbier V, Thibaudeau $\mathrm{L}$, Theodoropoulos $\mathrm{C}$, et al. Tissue engineered humanized bone supports human hematopoiesis in vivo. Biomaterials. 2015;61: 103-14. doi:10.1016/j.biomaterials.2015.04.057. Demonstrated recapitulation of morphology and metabolic activity of bone in a subcutaneous model

64. Scotti C, Piccinini E, Takizawa H, Todorov A, Bourgine P, Papadimitropoulos A, et al. Engineering of a functional bone organ through endochondral ossification. Proc Natl Acad Sci U S A. 2013;110(10):3997-4002. doi:10.1073/pnas.1220108110. Demonstrated the humanized bone organ could be generated through ossification from cartilage template

65. Kuhn LT, Liu Y, Boyd NL, Dennis JE, Jiang X, Xin X, et al. Developmental-like bone regeneration by human embryonic stem cell-derived mesenchymal cells. Tissue Eng Part A. 2014;20(1-2): 365-77. doi:10.1089/ten.TEA.2013.0321.

66. Lenas P, Moos M, Luyten FP. Developmental engineering: a new paradigm for the design and manufacturing of cell-based products. Part I: from three-dimensional cell growth to biomimetics of in vivo development. Tissue Eng B Rev. 2009;15(4):381-94. doi:10.1089/ten.TEB.2008.0575.

67. Chan CK, Chen CC, Luppen CA, Kim JB, DeBoer AT, Wei K, et al. Endochondral ossification is required for haematopoietic stemcell niche formation. Nature. 2009;457(7228):490-4. doi:10.1038 /nature07547.

68. Mehlen P, Puisieux A. Metastasis: a question of life or death. Nat Rev Cancer. 2006;6(6):449-58.

69. Roodman GD. Mechanisms of bone metastasis. N Engl J Med. 2004;350(16):1655-64. doi:10.1056/NEJMra030831.

70. Yong C, Onukwugha E, Mullins CD. Clinical and economic burden of bone metastasis and skeletalrelated events in prostate cancer. Curr Opin Oncol. 2014;26(3):274-83. doi:10.1097 /cco.0000000000000071.

71. Coleman RE. Clinical features of metastatic bone disease and risk of skeletal morbidity. Clin Cancer Res. 2006;12(20):6243s-9. doi:10.1158/1078-0432.ccr-06-0931.

72. Taichman RS, Cooper C, Keller ET, Pienta KJ, Taichman NS, McCauley LK. Use of the stromal cellderived factor-1/CXCR4 pathway in prostate cancer metastasis to bone. Cancer Res. 2002;62(6):1832-7.

73. Shiozawa Y, Havens AM, Pienta KJ, Taichman RS. The bone marrow niche: habitat to hematopoietic and mesenchymal stem cells, and unwitting host to molecular parasites. Leukemia. 2008;22(5):941-50. doi:10.1038/leu.2008.48.

74. Chong MS, Lim J, Goh J, Sia MW, Chan JK, Teoh SH. Mol Pharm. 2014;11:2126-33.

75. Karnoub AE, Dash AB, Vo AP, Sullivan A, Brooks MW, Bell $\mathrm{GW}$, et al. Mesenchymal stem cells within tumour stroma promote breast cancer metastasis. Nature. 2007;449(7162):557-63. http://www.nature.com/nature/journal/v449/n 7162 /suppinfo/nature06188_S1.html.

76. Quante M, Tu SP, Tomita H, Gonda T, Wang SS, Takashi S, et al. Bone marrow-derived myofibroblasts contribute to the mesenchymal stem cell niche and promote tumor growth. Cancer Cell. 2011;19(2):257-72. doi:10.1016/j.ccr.2011.01.020.

77. Ono M, Kosaka N, Tominaga N, Yoshioka Y, Takeshita F, Takahashi R-u, et al. Exosomes from bone marrow mesenchymal 
stem cells contain a microRNA that promotes dormancy in metastatic breast cancer cells. Sci Signal. 2014;7(332):ra63.

78. Molloy AP, Martin FT, Dwyer RM, Griffin TP, Murphy M, Barry FP, et al. Mesenchymal stem cell secretion of chemokines during differentiation into osteoblasts, and their potential role in mediating interactions with breast cancer cells. Int J Cancer. 2009;124(2): 326-32. doi:10.1002/ijc.23939.

79. Burger JA, Kipps TJ. Chemokine receptors and stromal cells in the homing and homeostasis of chronic lymphocytic leukemia B cells. Leuk Lymphoma. 2002;43(3):461-6. doi:10.1080 /10428190290011921.

80. Wang W, Weng Y, Ren W, Zhang Z, Wang T, Wang J, et al. Biological roles of human bone morphogenetic protein 9 in the bone microenvironment of human breast cancer MDA-MB-231 cells. Am J Transl Res. 2015;7(9):1660-74.

81. Ishikawa F, Yoshida S, Saito Y, Hijikata A, Kitamura H, Tanaka S, et al. Chemotherapy-resistant human AML stem cells home to and engraft within the bone-marrow endosteal region. Nat Biotechnol. 2007;25(11):1315-21. doi:10.1038/nbt1350.

82. Buenrostro D, Park SI, Sterling JA. Dissecting the role of bone marrow stromal cells on bone metastases. BioMed Res Int. 2014;2014:875305. doi:10.1155/2014/875305.

83. Walker ND, Patel J, Munoz JL, Hu M, Guiro K, Sinha G, et al. The bone marrow niche in support of breast cancer dormancy. Cancer Lett. 2015. doi:10.1016/j.canlet.2015.10.033.

84. Ganguly SS, Li X, Miranti CK. The host microenvironment influences prostate cancer invasion, systemic spread, bone colonization, and osteoblastic metastasis. Front Oncol. 2014;4:364. doi:10.3389/fonc. 2014.00364.

85. Lescarbeau RM, Seib FP, Prewitz M, Werner C, Kaplan DL. In vitro model of metastasis to bone marrow mediates prostate cancer castration resistant growth through paracrine and extracellular matrix factors. PLoS ONE. 2012;7(8):e40372. doi:10.1371/journal. pone. 0040372 .

86. Sikes RA, Nicholson BE, Koeneman KS, Edlund NM, Bissonette EA, Bradley MJ, et al. Cellular interactions in the tropism of prostate cancer to bone. Int J Cancer. 2004;110(4):497-503. doi:10.1002/ijc.20153.

87. Reichert JC, Quent VM, Burke LJ, Stansfield SH, Clements JA, Hutmacher DW. Mineralized human primary osteoblast matrices as a model system to analyse interactions of prostate cancer cells with the bone microenvironment. Biomaterials. 2010;31(31): 7928-36. doi:10.1016/j.biomaterials.2010.06.055.

88. Pathi SP, Kowalczewski C, Tadipatri R, Fischbach C. A novel 3-D mineralized tumor model to study breast cancer bone metastasis. PLoS ONE. 2010;5(1):e8849. doi:10.1371/journal.pone.0008849.

89. Fischbach C, Chen R, Matsumoto T, Schmelzle T, Brugge JS, Polverini PJ, et al. Engineering tumors with 3D scaffolds. Nat Methods. 2007;4(10):855-60. doi:10.1038/nmeth1085.

90. Sieh S, Lubik AA, Clements JA, Nelson CC, Hutmacher DW. Interactions between human osteoblasts and prostate cancer cells in a novel 3D in vitro model. Organogenesis. 2010;6(3):181-8.

91. Wang G, Haile S, Comuzzi B, Tien AH, Wang J, Yong TM, et al. Osteoblast-derived factors induce an expression signature that identifies prostate cancer metastasis and hormonal progression. Cancer Res. 2009;69(8):3433-42. doi:10.1158/0008-5472.CAN-08-3506.

92. Andersen C, Bagi CM, Adams SW. Intra-tibial injection of human prostate cancer cell line CWR22 elicits osteoblastic response in immunodeficient rats. J Musculoskelet Nueronal Interact. 2003;3(2):148-55.

93. Hensley PJ, Kyprianou N. Modeling prostate cancer in mice: limitations and opportunities. J Androl. 2012;33(2):133-44. doi:10.2164/jandrol.111.013987.

94. Rosol TJ, Tannehill-Gregg SH, LeRoy BE, Mandl S, Contag CH. Animal models of bone metastasis. Cancer. 2003;97(3 Suppl): 748-57. doi:10.1002/cncr.11150.
95. Nemeth JA, Harb JF, Barroso Jr U, He Z, Grignon DJ, Cher ML. Severe combined immunodeficient-hu model of human prostate cancer metastasis to human bone. Cancer Res. 1999;59(8):198793.

96. Moreau JE, Anderson K, Mauney JR, Nguyen T, Kaplan DL, Rosenblatt $\mathrm{M}$. Tissue-engineered bone serves as a target for metastasis of human breast cancer in a mouse model. Cancer Res. 2007;67(21):10304-8. doi:10.1158/0008-5472.can-07-2483.

97. Chong Ms, Chan J. In: Lentivirus gene engineering protocols. Humana Press; 2010. p. 135-147.

98. Born A-K, Lischer S, Maniura-Weber K. Watching osteogenesis: life monitoring of osteogenic differentiation using an osteocalcin reporter. J Cell Biochem. 2012;113(1):313-21. doi:10.1002 /jcb.23357.

99. van der Horst G, van der Pluijm G. Preclinical imaging of the cellular and molecular events in the multistep process of bone metastasis. Future Oncol. 2012;8(4):415-30. doi:10.2217 /fon. 12.33 .

100. Seib FP, Berry JE, Shiozawa Y, Taichman RS, Kaplan DL. Tissue engineering a surrogate niche for metastatic cancer cells. Biomaterials. 2015;51:313-9. doi:10.1016/j.biomaterials.2015.01.076.

101.• Holzapfel BM, Wagner F, Loessner D, Holzapfel NP, Thibaudeau L, Crawford R, et al. Species-specific homing mechanisms of human prostate cancer metastasis in tissue engineered bone. Biomaterials. 2014;35(13):4108-15. doi:10.1016/j. biomaterials.2014.01.062. Highlights the species-specificity of prostate cancer-bone interactions

102. Chong MSK. Experimental models of bone metastasis: opportunities for the study of cancer dormancy. Adv Drug Deliv Rev. 2015;94:141-50. doi:10.1016/j.addr.2014.12.007. Discusses the use of humanised mouse models for studies on cancer dormancy

103. Barrett JM, Mangold KA, Jilling T, Kaul KL. Bi-directional interactions of prostate cancer cells and bone marrow endothelial cells in three-dimensional culture. Prostate. 2005;64(1):75-82. doi:10.1002/pros.20206.

104. Nguyen LH, Annabi N, Nikkhah M, Bae H, Binan L, Park S, et al. Vascularized bone tissue engineering: approaches for potential improvement. Tissue Eng B Rev. 2012;18(5):363-82. doi:10.1089/ten.TEB.2012.0012.

105. Hofmann A, Ritz U, Verrier S, Eglin D, Alini M, Fuchs S, et al. The effect of human osteoblasts on proliferation and neo-vessel formation of human umbilical vein endothelial cells in a long-term $3 \mathrm{D}$ co-culture on polyurethane scaffolds. Biomaterials. 2008;29(31):4217-26. doi:10.1016/j.biomaterials.2008.07.024.

106. Dohle E, Fuchs S, Kolbe M, Hofmann A, Schmidt H, Kirkpatrick CJ. Sonic hedgehog promotes angiogenesis and osteogenesis in a coculture system consisting of primary osteoblasts and outgrowth endothelial cells. Tissue Eng A. 2010;16(4):1235-7. doi:10.1089 /ten.TEA.2009.0493.

107. Fuchs S, Ghanaati S, Orth C, Barbeck M, Kolbe M, Hofmann A, et al. Contribution of outgrowth endothelial cells from human peripheral blood on in vivo vascularization of bone tissue engineered constructs based on starch polycaprolactone scaffolds. Biomaterials. 2009;30(4):526-34. doi:10.1016/j. biomaterials.2008.09.058.

108. Liu Y, Teoh SH, Chong MS, Yeow CH, Kamm R, Choolani M, et al. Contrasting effects of vasculogenic induction upon biaxial bioreactor stimulation of mesenchymal stem cells and endothelial progenitor cells cocultures in 3D scaffolds under in vitro and in vivo paradigms for vascularized bone tissue engineering. Tissue Eng A. 2012. doi:10.1089/ten.TEA.2012.0187.

109. Marlow R, Honeth G, Lombardi S, Cariati M, Hessey S, Pipili A, et al. A novel model of dormancy for bone metastatic breast cancer cells. Cancer Res. 2013. doi:10.1158/0008-5472.can-13-0991. 
110. Ghajar CM, Peinado H, Mori H, Matei IR, Evason KJ, Brazier H, et al. The perivascular niche regulates breast tumor dormancy. Nat Cell Biol. 2013;15(7):807-17. doi:10.1038/ncb2767.

111. Mirabello L, Troisi RJ, Savage SA. Osteosarcoma incidence and survival rates from 1973 to 2004. Cancer. 2009;115(7):1531-43.

112. Ragland BD, Bell WC, Lopez RR, Siegal GP. Cytogenetics and molecular biology of osteosarcoma. Lab Invest. 2002;82(4):36573.

113. Ottaviani G, Jaffe N. The epidemiology of osteosarcoma. In: Jaffe $\mathrm{N}$, Bruland OS, Bielack S, editors. Pediatric and adolescent osteosarcoma, Cancer treatment and research, vol. 152. New York: Springer US; 2010. p. 3-13. doi:10.1007/978-1-4419-0284-9_1.

114. Guijarro MV, Ghivizzani SC, Gibbs CP. Animal models in osteosarcoma. Front Oncol. 2014;4:189. doi:10.3389/fonc.2014.00189.

115. Mueller F, Fuchs B, Kaser-Hotz B. Comparative biology of human and canine osteosarcoma. Anticancer Res. 2007;27(1A):155-64.

116. Kochevar D, Kochevar J, Garrett L. Low level amplification of csis and c-myc in a spontaneous osteosarcoma model. Cancer Lett. 1990;53(2):213-22.

117. Dernell W, Ehrhart N, Straw R, Vail D. Tumors of the skeletal system. Small Anim Clin Oncol. 2001;3:378-417.

118. Ranieri G, Gadaleta CD, Patruno R, Zizzo N, Daidone MG, Hansson MG, et al. A model of study for human cancer: spontaneous occurring tumors in dogs. Biological features and translation for new anticancer therapies. Crit Rev Oncol Hematol. 2013;88(1):187-97. doi:10.1016/j.critrevonc.2013.03.005.

119. Withrow S, Thrall D, Straw R, Powers B, Wrigley R, Larue S, et al. Intra-arterial cisplatin with or without radiation in limb-sparing for canine osteosarcoma. Cancer. 1993;71(8):2484-90.

120. Schiffman JD, Breen M. Comparative oncology: what dogs and other species can teach us about humans with cancer. Philos Trans R Soc Lond Ser B Biol Sci 2015;370(1673). doi:10.1098 /rstb.2014.0231.

121. Tovar C, Graves B, Packman K, Filipovic Z, Higgins B, Xia M, et al. MDM2 small-molecule antagonist RG7112 activates p53 signaling and regresses human tumors in preclinical cancer models. Cancer Res. 2013;73(8):2587-97. doi:10.1158/00085472.can-12-2807.

122. Tu B, Du L, Fan Q-M, Tang Z, Tang T-T. STAT3 activation by IL6 from mesenchymal stem cells promotes the proliferation and metastasis of osteosarcoma. Cancer Lett. 2012;325(1):80-8. doi:10.1016/j.canlet.2012.06.006.

123. Su Y, Wagner ER, Luo Q, Huang J, Chen L, He BC, et al. Insulinlike growth factor binding protein 5 suppresses tumor growth and metastasis of human osteosarcoma. Oncogene. 2011;30(37): 3907-17.

124. Zhou X, Wei M, Wang W. MicroRNA-340 suppresses osteosarcoma tumor growth and metastasis by directly targeting ROCK1. Biochem Biophys Res Commun. 2013;437(4):653-8. doi:10.1016/j.bbrc.2013.07.033.

125. Vormoor B, Knizia HK, Batey MA, Almeida GS, Wilson I, Dildey $\mathrm{P}$, et al. Development of a preclinical orthotopic xenograft model of ewing sarcoma and other human malignant bone disease using advanced in vivo imaging. PLoS ONE. 2014;9(1):e85128. doi:10.1371/journal.pone.0085128.

126. Ndreu A, Nikkola L, Ylikauppila H, Ashammakhi N, Hasirci V. Electrospun biodegradable nanofibrous mats for tissue engineering. Nanomedicine (Lond). 2008;3(1):45-60. doi:10.2217 /17435889.3.1.45.

127. Zhang Y, Ni M, Zhang M, Ratner B. Calcium phosphate-chitosan composite scaffolds for bone tissue engineering. Tissue Eng. 2003;9(2):337-45. doi:10.1089/107632703764664800.

128. Villasante A, Marturano-Kruik A, Vunjak-Novakovic G. Bioengineered human tumor within a bone niche. Biomaterials. 2014;35(22):5785-94. doi:10.1016/j.biomaterials.2014.03.081.

129. Lamhamedi-Cherradi S-E, Santoro M, Ramammoorthy V, Menegaz BA, Bartholomeusz G, Iles LR, et al. 3D tissueengineered model of Ewing's sarcoma. Adv Drug Deliv Rev. 2014;79-80:155-71. doi:10.1016/j.addr.2014.07.012. 